\title{
Efficiency of food baits, synthetic attractants and trap type on Rhynchophorus ferrugineus (Olivier) trapping in Palm Plantations, Ismailia, Egypt by aggregation pheromone traps
}

\author{
A. El-Banna ${ }^{1}$, M.K. Abbas ${ }^{2}$, A. Hala ${ }^{3}$ and T.M. Ibrahim ${ }^{2}$ \\ (1) Central Laboratory for Palm Research, ARC, Egypt; (2) Plant Protection Research Institute, ARC, Egypt, \\ email: Mohamed.kma155@yahoo.com; (3) Central Laboratory for Organic Agriculture, ARC, Egypt
}

\begin{abstract}
El-Banna, A., M.K. Abbas, A. Hala and T.M. Ibrahim. 2019. Efficiency of food baits, synthetic attractants and trap type on Rhynchophorus ferrugineus (Olivier) trapping in palm plantations, Ismailia, Egypt by aggregation pheromone traps. Arab Journal of Plant Protection, 37(2): 149-150.

Number of captured weevils were significantly affected by trap types, where PICUSAN ${ }^{\circledR}$ trap gave the highest captured number during the experimental period, which lasted for 7 weeks. The combined effect of sugarcane honey, pheromone, ethyl acetate and pesticides gave more attractiveness than the other four combinations tested.

Keywords: Rhynchophorus ferrugineus, pheromone traps, kairmone.
\end{abstract}

\section{Introduction}

Pheromone trapping of the red palm weevil Rhynchophorus ferrugineus (Olivier) is considered an environmentally safe tool in the IPM adopted strategy worldwide in date palm plantations. Field trials were conducted in Kasassin District, Ismailia Governorate, Egypt, to enhance the RPW pheromone-trapping efficiency. The current study was carried out during two successive years from April 22, 2015 until October 10, 2016.

\section{Trapping efficiency}

Results indicated that captured weevils were significantly affected by trap types, where PICUSAN ${ }^{\circledR}$ trap gave the highest captured number during the experimental period, which lasted for 7 weeks, with 92 adult weevils captured, followed by the bucket trap with 75 weevils captured. Moreover, the combined effect of sugarcane honey, pheromone, ethyl acetate and pesticides gave more attractiveness than the other 4 tested combinations, with 78 adult weevils captured by this bait during the 8 weeks of the experiment, whereas the other four combinations captured 50, 37, 19 and 14 weevils. The least registered weevil's number was in sugarcane honey and pesticides. This might be due to the combined effect of such treatments. The efficacy of synthetic kairmone with different combinations on the attraction of weevils was also investigated. The best combination was water, aggregation pheromone, palm tissue and molasses $(15 \%)$ in water. This combination collected around 246 adults during the 10 weeks period of the experiment. The mixture EtAc + EtOH (1:3) was able to boost pheromone and was almost as effective as the use of the complete bait. Ethyl acetate alone did not improve the attraction power for the aggregation pheromone. In addition, sex ratio was calculated and it was found that male:female ratio was $1: 2.1$.

\section{Monitoring and early detection}

Monitoring the activity of the RPW is essential for keeping a close watch on the establishment and subsequent build-up of the pest population. Early detection, on the other hand, is crucial to avoid the death of palms and is the key to the success of any IPM strategy adopted to combat this pest. Using of PICUSAN ${ }^{\circledR}$ trap with a bait of sugarcane honey, pheromone, ethyl acetate and pesticides or Water, aggregation pheromone, palm tissue and molasses $15 \%$ in water is recommended. Trapping adults of $R$. ferrugineus with food-baited traps to monitor the activity of the pest, or mass trapping of adults in the field has been recommended as a component of the weevil's IPM program in coconut plantations. 


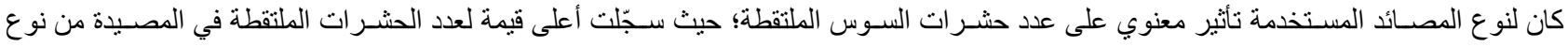

بيكوسان (PICUSAN وذللك خلال فترة تنفيذ التجربة التي دامت لمدة سبعة أسابيع. كما تحقَّت أفضل النتائج في جذب الحشرة بالثأثير المشترك للخليط المكوّن

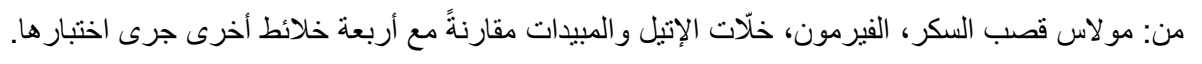
كلمات مفتاحية: Rhynchophorus ferrugineus، مصائد فيرمونية، كيرمون.

\section{References}

Abbas, M.K. 2005. Integrated management for controlling red palm weevil. Ph.D. Thesis. Faculty of Agriculture, Ain Shams University, 166 pp.

Abraham, V.A. and C. Kurian. 1975. An integrated approach to the control Rhynchophorus ferrugineus, the red weevil of coconut palm. In: Proceedings of the 4th Session of the FAO Technical Working Party on Coconut Production, Protection and Processing, 14-2, Kingston, Jamaica. https://doi.org/10.3923/je.2010.54.59

El-Sebay, Y. 2003. Ecological studies on the red palm weevil, Rhynchophorus ferrugineus (Coleoptera: Curculionidae) in Egypt. Egyptian Journal for Agricultural Research, 81: 523-529.

Guarino, S., P. Lo Bue, E. Peri and S. Coalzza. 2011. Responses of Rhynchophorus ferrugineusadults to selected synthetic palm esters: Electroanemographic studies and trap catches in an urban environment. Pest Management Science, 67: 77-81. https://doi.org/10.1002/ps.2035

Hallett, R.H., A.C. Oehlschlager and J.H. Borden. 1999. Pheromone trapping protocols for the Asian palm weevil, Rhynchophorus ferrugineus Olivier (Coleoptera: Curculionidae). International Journal of Pest Management, 45: 231-237. https://doi.org/10.1080/096708799227842
Jaffé, K., P. Sanchez, H. Cerda, J.V. Hernandez, R. Jaffé, N. Urdaneta, N. Guerra, R. Martinez and B. Miras. 1993. Chemical ecology of the palm weevil Rhynchophorus palmarum L. (Coleoptera: Curculionidae): attraction to host plants and to a maleproduced aggregation pheromone. Journal of Chemical Ecology, 19: 1703-1720. https://doi.org/10.1007/bf00982302

Robin, M., R. Faleiro, A. Jacas and P. Vidyasagar. 2013. Biology and management of the red palm weevil, Rhynchophorus ferrugineus. Page 33. In: Potential Invasive Pests of Agricultural Crops. J. Peña (ed.). $1^{\text {st }}$ Edition, CABI, United Kingdom. https://doi.org/10.13140/2.1.1029.1202

S.A.S Institute. 1985. SAS user's guide: statistics, 5th Ed SAS Institute, Cary, NC

Vacas, S., J. Primo and V. Navarro-Llopis. 2013. Advances in the use of trapping systems for Rhynchophorus ferrugineus (Coleoptera: Curculionidae): traps and attractants. Journal of Economic Entomology, 106: 1739-1746. https://doi.org/10.1603/EC13105 